\section{The Millennials' Effect: How Can Their Personal Values Shape the Future Business Environment of Industry 4.0?}

\author{
Rok Črešnar \\ PhD student at the University of Maribor, Faculty of Economics and Business, \\ Slovenia \\ rok.cresnar@student.um.si
}

\section{Senta Jevšenak}

Master student at the University of Maribor, Faculty of Arts, Slovenia

senta.jevsenak@gmail.com

\begin{abstract}
The main purpose of this paper is to assess a possible impact millennials will have on the future business environment of Industry 4.0, based on their personal value orientations. Millennials are taking over important roles in organizations, but their personal values are significantly different from those of older generations. This paper shows that, based on the Schwartz's value survey with $N=371$ Slovenian respondents, millennials are in general more inclined toward values connected to personal growth and freedom from anxiety, emphasizing self-transcendence and openness to change, than toward self-protection and anxiety avoidance, understating conservation and self-enhancement values. These cognitions can have significant implications in shaping the future business environment of Industry 4.0, as it can become more open, understanding, collaborative, accepting, and generally more supporting, thus creating the evident millennials' effect. Even though millennials are in general well prepared for the future business environment, organizations will have to, in order to retain the millennials, reshape their current organizational environment to better reflect the millennials' views.
\end{abstract}

Keywords: millennials, Industry 4.0, personal values, predicting business environment, business ethics, digitalization, Schwartz value survey

\section{Introduction}

Millennials, the generation often recognized as being born between 1980 and 2005, is increasingly taking over important roles in organizations and making a significant impact on the current business environment (Twenge et al., 2012; Weber, 2017; Akers, 2018). As the largest generation born, millennials are different than previous generations (Twenge, 2010), and nowhere is this more evident than in their attitudes and behaviors (Gibson et al., 2009).

Individuals' attitudes and behaviors are in large part driven by their personal values (Rokeach, 1973; Ajzen 1991; Schwartz, 1992; Schwartz, 1994); thus, in this study, they can present a base for a key insight into understanding the way future business environment will develop. This fact is also widely recognized by scientists, who continuously find that personal values indeed have a predictive and
ORIGINAL SCIENTIFIC PAPER

RECEIVED: NOVEMBER 2018

REVISED: FEBRUARY 2019

ACCEPTED: FEBRUARY 2019

DOI: 10.2478/ngoe-2019-0005

UDK: 005.5:658.5:316.34

JEL: M21, D90, M59

Citation: Črešnar, R., \& Jevšenak, S. (2019). The Millennials' Effect: How Can Their Personal Values Shape the Future Business Environment of Industry 4.0? Naše Gospodarstvo/Our Economy, 65(1), 57-65. DOI: 10.2478/ngoe-2019-0005
NG

NAŠE GOSPODARSTVO OUR ECONOMY

\begin{tabular}{l|l|l} 
Vol. 65 & No.1 2019 \\
\hline
\end{tabular}

pp. $57-65$ 
influential impact on the behaviors and attitudes of the individuals (Ajzen, 1991; Schwartz, 1992; Verplanken, 2004; Roccas \& Sagiv, 2010; Weber, 2017).

Personal values act as a cognitive filter of sorts. They reflect individual's abstract personal perceptions of the correct behavior into the real environment (Spranger, 1928; Rokeach, 1973; Schwartz, 1992). However, not all personal values are of equal importance to an individual, which is attributed to individual's different personal motivations, beliefs, goals, etc. (Schwartz, 2012; Schwartz et al., 2012). This creates a gap between the types of personal values different generations hold, which has significant implications in the workplace and in a larger frame, in the business environment (Gibson et al., 2009; Twenge et al., 2012; Weber, 2017).

Older generations of employees and managers such as Gen X (born between 1965-1980) hold different sets of personal values than younger generations (Sessa et al., 2007; Gibson, et al., 2009; Twenge et al., 2012; Weber, 2017). They are usually more inclined toward security, conformity, tradition, benevolence, and universalism than millennials (see $\mathrm{Ng}$ et al., 2010; Twenge, 2010; Nedelko 2015; Weber, 2017). This means that the current business environment was fundamentally shaped by the personal values of previous generations, and that millennials will shape it according to their prominent personal values. Thus, in this paper, we put forward the notion that the potential impact of millennials on the future business environment can be predicted on the basis of their personal values. Pairing these cognitions with the current trends in business and economic practice presents an important opportunity for applicable study.

Current trends in economic and business practice are nowadays firmly focused on the changes that digitalization, which is showing itself in the form of the Industry 4.0 phenomenon, will bring (Müller et al., 2018; Bonilla et al., 2018; Piccarozzi et al., 2018). Digitalization has, especially in the last decade, had a severe impact on the economic system (Scholz et al., 2018) and, within it, the organizations (Mohelska \& Sokolova, 2018). Organizations can be considered as core entities of an economic system (Perrow, 1991); therefore, their role in the development of the future business environment is paramount.

The pillars and orientations of Industry 4.0, which are aiming to profoundly change the normal business practice through digitalization, automation, and artificial intelligence will also have a severe impact on employees (Črešnar \& Nedelko, 2017; Schneider, 2018; Črešnar et al., 2019). The complementarity between the personal values of millennials, who are the future employees, and the organization's requirements in the future business economy will also have to be addressed. But, more importantly, no studies have yet presented the potential impact millennials might have on the future business environment, looking through the lenses of their personal values.

This paper offers significant contributions to business practice, management, and other social academic disciplines. It offers a theoretical assessment model of the changes that the millennial generation will likely bring to the future business environment, based on their personal values. Moreover, it presents personal value orientations of 371 Slovene millennials based on Schwartz's (2012) value survey. Results provide the starting point, which organizations can use to plan the recruitment processes, succession, training and learning, development, and other employee-related strategic activities.

\section{Theoretical Background}

\section{Concept of Personal Values}

The deep nature of personal values has, through the decades, been studied by scientists who were fascinated with how those values ultimately affect human behavior (Kluckhohn, 1951; Rokeach, 1973; Schwartz, 1992, Schwartz, 1994; Schwartz, 2012). Looking at personal values from a purely applicable and practical standpoint, such as considered in this paper, the concept can be applied in various scientific fields, e.g., in humanities, social sciences, etc. (Sagiv et al., 2017). Personal values are most often described as a set of abstract goals, beliefs, etc. that influence a person's view of the world (Rokeach, 1973; Schwartz, 1992). But we can describe them, as a cognitive filter, through which a person is judging specific real-world circumstances. The study of personal values has therefore attracted scientists in various fields in trying to describe or predict the specific behavior of certain individuals (see Grojean et al., 2004; Bruno \& Lay, 2008; Twenge, 2010; Nedelko, 2015; Weber, 2017, etc.). Specifically, in the context of business economy, scientists have most often gravitated toward linkages between personal values and leadership or management (Grojean et al., 2004; Bruno \& Lay, 2008; Nedelko, 2015; Akers, 2018), personal values and organizational ethics or social responsibility (Poto \& Lay, 2008; Nedelko, 2015; Nedelko al., 2017), personal values and management innovativeness (Nedelko \& Potočan, 2019), the role of personal values in supporting innovativeness (Dabic, Potocan, \& Nedelko, 2017), etc.

Through the extensive development of the concept, scientists were starting to notice a pattern of consistent (universal) structure that personal values have (Rokeach, 1973; Schwartz, 1992). In this paper, we base our cognitions on Schwartz's (1992; 1994; 2012) theory, who proposed the following structure of personal values in 1992 but refined 
the concept through the years. Schwartz (1992) proposed 10 specific dimensions or types of personal values, which differ according to a person's motivation. These are, namely:

1. Power: explaining persons inclinations towards authority and wealth or to dominate and control other people.

2. Achievement: focusing on a person's capacities, competencies, and ultimately personal success.

3. Hedonism: a pure focus on self-gratification and pleasurable enjoyment of life.

4. Stimulation: tendencies toward exciting, varied, and challenging life.

5. Self-direction: emphasizing freedom, creativity, and curiosity.

6. Universalism: explaining tolerance, understanding, and tendency to protect nature and all living creatures.

7. Benevolence: reflecting honesty, helpfulness, and forgiveness toward others.

8. Tradition: accepting the culture or religion along with customs and ideas of the society.

9. Conformity: explaining obedience, politeness, and resistance to actions that may harm others.

10. Security: emphasizing on stability, safety and harmony of the country, relationships, and of the individual.

From these 10 main types of personal values, four higher dimensions became clearly visible, namely, (1) self-enhancement, joining power, hedonism, and achievement; (2) openness to change, explaining stimulation, self-direction, and hedonism; (3) self-transcendence, encompassing benevolence and universalism; and lastly (4) conservation, reflecting security, conformity, and tradition. The first two higher dimensional values reflect personal interest, and the second two reflect social interest of a person (Schwartz, 1992). Still, these dimensions are even more expended to the level of sectors. Self-transcendence and openness to change fall under the sector of personal growth and freedom from anxiety, where conservation and self-enhancement fall under self-protection and anxiety avoidance sector (Schwartz et al., 2012). The theory has since 1992 expanded and became more refined (see Schwartz et al., 2012).

An important theoretical notion, on which we base the applicative results of this paper, states that personal values are able to predict individual's future behavior, the concept is presented in Figure 1 (Ajzen, 1991; Schwartz, 1992; Verplanken, 2004; Roccas \& Sagiv, 2010; Weber, 2017).
The strength of this concept is in the idea that personal values create attitudes (Schwartz, 1992; Roccas \& Sagiv, 2010; Schwartz, 2012), which in turn influence behavioral intention that results in a certain behavior (Ajzen, 1991). This means that, for purposes of this study, we are using this concept to predict the changes in the future business environment, which will be influenced by the millennials’ personal values.

\section{Millennials and Their Personal Values}

Millennials are, in general, different than previous generations (Twenge, 2010; Ng et al., 2010; Twenge et al., 2012; Weber, 2017; Akers, 2018). Born between the 1980 and 2000 (or sometimes 2005), it is estimated that millennials are the largest generation ever to be born, counting around 80 million individuals. This generation grew up in the era of rapid advances in digital technology and computation, giving them a unique information-based life experience, which previous generations did not have (Weber, 2017). These profoundly different life experiences have shaped millennials’ personal values differently from those of previous generations. As Weber (2017, p. 519) argues, specific personal values have varying degrees of importance for different generations, which is often the result of the aforementioned different life experiences.

In general, the millennials are considered to be more flexible, adaptive, open to change, and hedonistically oriented than Generation X, who are more conservative and value more tradition in the sense of stability, hard work, and security (Lester, 2011; Ahn \& Ettner, 2014; Akers, 2018). Furthermore, millennials in management have different values in the sense that they are more self-centered and less other-centered, meaning that they prioritize self-enhancement more than self-transcendence. This also reflects in the fact that they give more importance to the competencies and skills; however, it is peculiar that, at the same time, they also have higher moral values. Millennials also value friendship, love, and ambition more than previous generations (Gibson et al., 2009). Ng et al. (2010) find that millennials are prioritizing parts of the job, which are individualistically oriented, meaning that they want to be promoted fast and develop their competencies to become better at their job. At the same time, however, they value their lives outside of work. Weber (2017) also argues that high moral and ethical values make millennials prepared to enter today's business environment.

Figure 1. Theoretical Model of How Values Influence Behavior

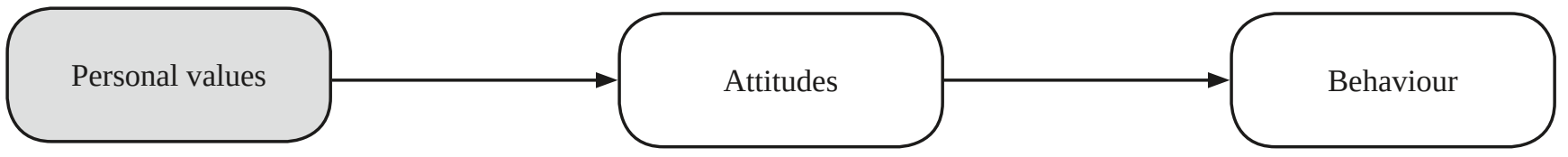

Source: Adapted from Ajzen, 1991; Schwartz, 1992; Schwartz, 1994 
With reference to research results from the studies of millennials' personal values from other Western and developed economies (Gibson et al., 2009; Ng et al., 2010; Twenge et al., 2012; Weber, 2017), we can postulate the following hypothesis.

Hypothesis: Millennials hold self-protection and anxiety avoidance sector values more prominently than values of personal growth and freedom from anxiety. Thus, they are emphasizing self-enhancing and conservation values more than self-transcending and openness to change values.

However, the business environment is constantly changing, and especially in the global business economy, trending more toward multidisciplinary approaches to problem-solving, teamwork, more democratic leadership, more important roles of employee creativity and productivity, outstanding ethics of employees and organizations, etc. These trends are, in a large part, based on the business practices that are typical for Industry 4.0-based business environment and were shaped by digitalization (Spath et al., 2013; Erol et al., 2016; Prifti, et al., 2017; Črešnar \& Nedelko, 2017; Scholz et al., 2018; Enke et al., 2018). Thus, these cognitions call for the reexamination of the personal values of the future employees and the role of personal values in future workplace environment.

\section{Effects of Digitalization on the Business Environment}

When pushing the paradigms of current science, both natural and social, there are a lot of discussions about the phenomenon of digitalization. This phenomenon has, in the last decade, caused profound changes in the natural environment, society, and, consequently, in the business economy (Scholz et al., 2018; Bonilla et al., 2018). Its importance for the progress of human species can be rivaled with such events as the development of agriculture or mastering the fire (Takács-Sánta, 2004; Scholz et al., 2018). Put in simple words, digitalization is a process of representing the real world with digital symbols using digital technologies (Scholz et al., 2018). But nowhere are its effects more evident than in the manufacturing and industrial sector, which gave rise to the phenomenon of Industry 4.0, where business digitalization is at its strongest (Bressanelli et al., 2018). Industry 4.0 aims for a new industrial revolution while integrating automation, Internet of Things, cyber-physical systems, artificial intelligence, and smart manufacturing (Wang et al., 2016; Roblek et al., 2016).

So, what are the expected effects of digitalization on the business environment? If we examine the issue through the lenses of which new competencies employees will have to have, we see that an increasingly multicultural environment will require employees to be more inclined toward teamwork, social interactions, collaborations, adaptivity, flexibility, ethics, etc. (Erol et al., 2016; Herold et al., 2016; Prifti et al., 2017, Enke et al., 2018) prompting a high need for benevolence and universalism values. Moreover, it is expected from employees to be highly creative, innovative, open to learning, emotionally mature, and able to self-manage (Erol et al., 2016; Herold et al., 2016; Prifti et al., 2017), which calls for high self-direction and stimulation values. But contrary to a different note, due to the high multicultural, multidisciplinary, and collaborative environment toward which business is apparently striving, personal values for power, security, achievement, and tradition are not as emphasized. However, they will be mandatory for future leaders (Bowels, 2015; Herold, 2016; Akers, 2018).

In consequence of these changes, the question of which values, attitudes, and behaviors employees have and how this affects the future industry becomes relevant. Therefore, an empirical examination to address this issue is needed.

\section{Methods}

\section{Sample and Procedures}

The data for this study were obtained with a survey in 2018 conducted among Slovenian young adults, who can be characterized by their age into the millennial generation. Addressing the cognition that this generation is technologically adapted, we conducted a survey online and spread it through the population with the help of social media tools. For the analysis in this study, we use $N=371$ returned questionnaires with no missing data. The sample size is approximately the same as the sample size in other studies of personal values in students (see Schwartz et al., 2012). Also, the sample is large enough for the analyses of mean values, to draw from it meaningful conclusions (Couper, 2000).

In the obtained sample, there are $58 \%$ of female respondents and $42 \%$ of male respondents. With regard to respondents' place of residence, $41.5 \%$ live in a large city and 58.5\% live in a suburban town or on a countryside. On average, respondents are 22.62 years old with a standard deviation of 2.85 years. The youngest respondent was 16 years old; the oldest respondent was 35 years old.

\section{Measures}

To measure personal values of millennials, a refined theory of personal values with a short value survey was used as a base for conducting a survey (Schwartz et al., 2012). In the survey, there were 26 items or individual values, which 
were then joined into constructs of 10 main types (subdimensions) of personal values according to the theory indications of where each item fits a subdimension (Schwartz, 1992; Schwartz, 1994; Schwartz, 2012; Schwartz et al., 2012). To grade personal values, millennials were able to select an answer on a 6-point Likert type scale, from $1=$ this is nothing like me to $6=$ this is very much like me. In previous studies of students' (approximately the same age as millennials) personal values with Schwartz value survey, 6-point scales were also used in Turkey, Switzerland, Israel, and Germany (see Schwartz et al., 2012).

\section{Results}

Statistics in Table 1 show interesting and peculiar rankings of personal values among Slovenian millennials, suggesting that further investigations are necessary. According to the results, at the forefront are personal values connected to personal growth and freedom from anxiety. The highest-ranked personal value of Slovenian millennials is benevolence $(\bar{y}=5.11 ; \sigma=.79)$. Following are self-direction $(\bar{y}=5.00 ; \sigma=.77)$, hedonism $(\bar{y}=4.87 ; \sigma=.88)$, and universalism $(\bar{y}=4.82 ; \sigma=.72)$. Next, personal values connected more to self-protection and anxiety avoidance come to the forefront. Namely, achievement $(\bar{y}=4.69 ; \sigma=1.02)$, security $(\bar{y}=4.46 ; \sigma=1.10)$, stimulation $(\bar{y}=4.15 ; \sigma=1.04)$, tradition $(\bar{y}=3.42 ; \sigma=1.56)$, conformity $(\bar{y}=3.40 ; \sigma=1.11)$, and, lastly, the lowest-ranked personal value is power $(\bar{y}=3.05 ; \sigma=1.06)$.

Table 1. Results of the Mean Value Analysis and Corresponding Ranks

\begin{tabular}{lcccc} 
Personal Value & Mean & $\begin{array}{c}\text { Standard } \\
\text { Deviation }\end{array}$ & Variance & Rank \\
\hline Benevolence & 5.11 & .79 & .62 & 1. \\
\hline Self-direction & 5.00 & .77 & .60 & 2. \\
\hline Hedonism & 4.87 & .88 & .78 & 3. \\
\hline Universalism & 4.82 & .72 & .52 & 4. \\
\hline Achievement & 4.69 & 1.02 & 1.04 & 5. \\
\hline Security & 4.46 & 1.10 & 1.22 & 6. \\
\hline Stimulation & 4.15 & 1.04 & 1.08 & 7. \\
\hline Tradition & 3.42 & 1.56 & 2.44 & 8. \\
\hline Conformity & 3.40 & 1.11 & 1.24 & 9. \\
\hline Power & 3.05 & 1.06 & 1.12 & 10. \\
\hline
\end{tabular}

Notes: Sample size is 371 ; in shaded fields are values connected to personal growth and freedom from anxiety; in unshaded fields are values connected to self-protection and anxiety avoidance.

Source: Author's calculations.

Results in Table 1 also show thought-provoking variability when examined through the lenses of rankings. As rankings of personal values decrease, i.e., lose their subjective importance in the sample, the variability of the results increases.
It is evident that personal values at the top of the rankings have lower standard deviations and variances (no. 1 = benevolence; $\sigma=.79 ; \mathrm{s}^{2}=.62$ ) than personal values at the bottom of the rankings (no. $10=$ power; $\sigma=1.06 ; \mathrm{s}^{2}=1.12$ ).

\section{Discussions and Recommendations}

\section{What Value Profile of the Millennials Do the Results Indicate?}

It is evident that, based on the millennials' personal values rankings, they will be striving more toward personal growth in the workplace. That notion falls in line with Industry 4.0 competence models, which encourage such endeavors (Erol et al., 2016; Prifti et al., 2017; Enke et al., 2018). On the same note, the millennials will also be more inclined toward ridding themselves of anxiety rather than only avoiding anxiety. This suggests a proactive behavior toward self-management, creativity, and openness toward new opportunities and toward other people, which is also needed from future employees (Prifti et al., 2017; Grzybowska \& Lupicka, 2017). The lack of their focus on tradition, security, and conformity further strengthens a case of their fit in the future business environment. With regard to self-enhancing values of power and achievement, these are not among top-ranked, even though other studies have found these to be more prominent in millennials (Ng et al., 2010; Twenge, 2010; Nedelko, 2015; Weber 2017; Akers, 2018). Thus, we reject our hypothesis, as clearly Slovene millennials categorically prioritize personal values of personal growth and freedom from anxiety. This peculiar fact may have some implications in former political orientation, where in the socialistic/communistic Yugoslav regime such communal values were heavily encouraged (Rokeach, 1979). Thus, it is possible that some of the "old" principles were transferred from parents to children with means of childhood value indoctrination (Baer Jr., 1977), which is showing up nowadays in the form of our results.

With regard to the higher variability of low-ranked personal values, the results suggest that, in general, the millennials are homogeneous in self-transcending values and in part in openness to change. This indicates that these personal values are well rooted in society. However, with regard to conservation and self-enhancement values, high variability suggest that millennials have different goals or motives when striving for power and achievement or emphasizing conservation. Therefore, although the millennials are, in general, benevolent and open, there are also those among them who strive for power and achievement but, at the same time, remain benevolent and open. Overall, with regard to 
business practice, we can conclude that millennials are prepared for the future business environment of Industry 4.0, looking through the lenses of their personal values. Even though a recent survey found that, based on their expectations and disappointments, they might not be prepared for it (Deloitte, 2018).

\section{How Will Millennials Impact the Future Business Environment?}

Employers, practitioners, and scientists have voiced their requirements for employees' competencies and demeanor in the future Industry 4.0. But millennials, special as though they are, will undoubtedly shape it to suit their values; therefore, the "millennials' effect” will be evident. For instance, millennials who are supposed to be self-centered in comparison with previous generations (Twenge et al., 2012; Weber, 2017) are not showing these tendencies according to the results of this paper. Focusing more on others may indicate a more open, collaborative, and accepting working environment. High ranking of hedonism also indicates that personal time and enjoyment of life will be an important factor; thus, it can be expected that millennials will require more vacation time and work harder during normal working time.

In contrary with older generation employees (Gibson et al., 2009; Twenge, 2010; Weber, 2017), millennials do not place a lot of emphasis on conservation values of security, tradition, and conformity, which can further suggest a more open and free future business environment. However, it is curious that, in the case of Slovenia, recent and past study results indicate that Slovenian managers also do not put crucial importance on these values, in comparison with other developed economies (Piciga \& Musek et al., 1992; Nedelko \& Potočan, 2019), which further strengthens the implications the former regime had on personal value development.

Some millennials undoubtedly do place a lot of emphasis on self-enhancing values (Ng et al., 2010; Weber, 2017). This can be a result of their upbringing, as they were, through television and later on through social media, more subjected to various success stories of famous people, which were put forward as highly valued endeavors in the society (Weber, 2017). But it is suggested that millennials with high self-enhancing values may make good leaders in the future Industry 4.0 (Bowels, 2015; Akers, 2018). This, coupled with high self-transcending values, which are according to this study highly ranked and homogeneous, can support the notion of more open, understanding, collaborative, accepting, and generally supporting future business environment.
With regard to millennials' effect on the organizations and their management, several key points can be outlined. A growing projected shortage of workers in Western economies suggests that millennials will have the option to choose between organizations for which they wish to work for (Ng et al., 2010). This means that organizations should be prepared and have strategies in place to ensure low employee turnover rate and have reward systems in place to ensure that millennials will be loyal to organizations that, according to Lancaster and Stillman (2002), are currently not. Setting the proper work environment will be key to retaining millennials; here, the results from personal values profiles can be significant. To reflect their general personal values, the future business environment should be oriented to enable millennials to develop, have more available leisure time, while reflecting universal, progressive, and benevolent attitudes toward others and the environment. These cognitions can thus enable organizations, especially in the manufacturing sector, which is the most tightly connected to Industry 4.0 (Müller et al., 2018) a comprehensive framework to plan the recruitment processes, succession, work design, training and learning, development, etc.

\section{Future Directions and Study Limitations}

To further enhance the cognitions, additional studies on millennials' personal values should be conducted with connection to the future business environment of Industry 4.0. Specifically, the comparison between the millennials from different parts of the Western world, and also comparison between different age groups within the millennial generation, can add benefit toward more comprehensively understanding the personal value dynamics and consequently their impact. To obtain a more accurate picture of their impact, the millennials' attitudes toward digitalization-based business environment can further enrich the existing models.

Several limitations of the study can also be outlined. The sample is conveniently taken; thus, generalizations of the results are more difficult to make. Also, the sample is taken from the Slovenian population, which can have some implications in the results due to the Slovenian gradual transitional approach to a free market economy. A self-assessment method was used, which can also influence the results (Lau et al., 2016). Some studies that were cited regarding the personal values of millennials; for instance, $\mathrm{Ng}$ et al. (2010), Twenge et al. (2012), and Weber (2017) may have implications in the results, as they were mostly made among the North American population. Last, predictions were made based on the suggested future behavior through the lenses of personal values, which may not comprehensively reflect the real-world circumstances that influence behavior (Ajzen, 1991; Schwartz, 1994). 


\section{Conclusion}

The main aim of this study was to assess the personal values of millennials and determine how they fit into the future business environment of Industry 4.0 and how will they change it with their attitudes and behaviors. First, with regard to the importance millennials place on specific personal values, results show that millennials are focusing more on personal growth and freedom from anxiety than on self-protection and anxiety avoidance. Personal values connected with these tendencies suggest that they can fit into the future business environment, are compatible with it, and complementary to it. Second, with regard to their impact on the future business environment, arguments can be made that, based on their personal values, the future business environment of Industry 4.0 will be more supportive, collaborative, teamwork oriented, open, and understanding toward others. Third, overall, we can conclude that millennials' special personal value orientations will undoubtedly cause changes in the future business environment. This environment will reflect the more progressive beliefs and attitudes millennials grew up with. Therefore, organizations, especially in the manufacturing sector, should also prepare their environment to better suit millennials' value orientations in order to secure their productivity, happiness, and loyalty to minimize the turnover.

\section{References}

Ahn, M.J., \& Ettner, L.W. (2014). Are leadership values different across generations?: A comparative leadership analysis of CEOs v. MBAs. Journal of Management Development, 33(10), 977-990. https://doi.org/10.1108/JMD-10-2012-0131

Ajzen, I. (1991). The theory of planned behavior. Organizational Behavior and Human Decision Processes, 50, 179-211. https://doi. org/10.1016/0749-5978(91)90020-T

Akers, K. L. (2018). Leading after the boom: Developing future leaders from a future leader's perspective. Journal of Management Developmen, 37(1), 2-5. https://doi.org/10.1108/JMD-03-2016-0042

Baer Jr, R. A. (1977). Values clarification as indoctrination. The Educational Forum, 41(2), 155-165. doi:10.1080/00131727709336229 https://doi.org/10.1080/00131727709336229

Bonilla, S. H., Silva, H. R., da Silva, M. T., Gonçalves, R. F., \& Sacomano, J. B. (2018). Industry 4.0 and sustainability implications: A scenario-based analysis of the impacts and challenges. Sustainability, 10(10), 3740. doi:doi.org/10.3390/su10103740 https://doi. org/10.3390/su10103740

Bowels, M. (2015). Capabilities for leadership and management in the digital age. Melbourne: Working Futures.

Bressanelli, G., Adrodegari, F., Perona, M., \& Saccani, N. (2018). Exploring how usage-focused business models enable circular economy through digital technologies. Sustainability, 10(3), 639. doi:10.3390/su10030639 https://doi.org/10.3390/su10030639

Bruno, L. F., \& Lay, E. G. (2008). Personal values and leadership effectiveness. Journal of Business Research, 61, 678-683. https://doi. org/10.1016/j.jbusres.2007.06.044

Couper, M. P. (2000). Web surveys: A review of issues and approaches. Public Opinion Quarterly, 64(4), 464-494. https://doi. org/10.1086/318641

Črešnar, R., \& Nedelko, Z. (2017). The role and importance of employee's productivity in Industry 4.0. In M. Bezpartochnyi (Ed.), Mechanisms of interaction between competitiveness and innovation in modern international economic relations (pp. 120-133). Riga, Latvia: ISMA University.

Črešnar, R., Nedelko, Z., \& Jevšenak, S. (2019). Strategies and tools for knowledge management in innovation and the future industry. In H. Almeida, \& B. Sequeira (Eds.), The role of knowledge transfer in open innovation (pp. 179-202). Hershey, PA: IGI Global. doi:10.4018/978-1-5225-5849-1.ch009 https://doi.org/10.4018/978-1-5225-5849-1.ch009

Dabic, M., Potocan, V., \& Nedelko, Z. (2016). Personal values supporting enterprises' innovations in the creative economy. Journal of the Knowledge Economy, 8(4), 1241-1261. doi:10.1007/s13132-016-0354-z https://doi.org/10.1007/s13132-016-0354-z

Deloitte. (2018). 2018 Deloitte Millennial Survey: Millennials disappointed in business, unprepared for Industry 4.0. Global: Deloitte Touche Tohmatsu Limited.

Enke, J., Glass, R., Kreß, A., Hambach, M., Tisch, M., \& Metternich, J. (2018). Industrie 4.0 - Competencies for a modern production system: A curriculum for learning factories. Advanced Engineering Education \& Training for Manufacturing Innovation"8th CIRP Sponsored Conference on Learning Factories (CLF 2018). 23, pp. 867-272. Partas: Elsevier. doi:10.1016/j.promfg.2018.04.028 https:// doi.org/10.1016/j.promfg.2018.04.028

Erol, S., Jäger, A., Hold, P., Ott, K., \& Sihn, W. (2016). Tangible Industry 4.0: a scenario-based approach to learning for the future of production. Procedia CIRP (pp.13-18). Gjøvik: Elsevier B.V.

Gibson, J. W., Greenwood, R. A., \& Murphy, Jr, E. F. (2009). Generational differences in the workplace: personal values, behaviors, and popular beliefs. Journal of Diversity Management, 4(3), 1-9. https://doi.org/10.19030/jdm.v4i3.4959

Grojean, M. W., Resick, C. J., Dickson, M. W., \& Smith, D. B. (2004). Leaders, values, and organizational climate: Examining leadership strategies for establishing an organizational climate regarding ethics. Journal of Business Ethics, 55, 223-241. https://doi. org/10.1007/s10551-004-1275-5 
Grzybowska, K., \& Łupicka, A. (2017). Key competencies for Industry 4.0. Economics \& Management Innovations, 1(1), 250-253. https:// doi.org/10.26480/icemi.01.2017.250.253

Herold, G. (2016). Leadership in the fourth industrial revoulution. Dallas, TX: Stanton Chase.

Kluckhohn, C. (1951). Values and value orientations in the theory of action. In T. Parsons, \& E. A. Shils (Eds.), Toward a general theory of action (pp. 388-433). New York: Harper. https://doi.org/10.4159/harvard.9780674863507.c8

Lancaster, L. C., \& Stillman, D. (2002). When generations collide: Who they are. Why they clash. How to solve the generational puzzle at work. New York: Harper Collins.

Lau, P. Y., McLean, G. N., Lien, B. H., \& Hsu, Y. C. (2016). Self-rated and peer-rated organizational citizenship behavior, affective commitment, and intention to leave in a Malaysian context. Personnel Review, 45(3), 569-592. doi:10.1108/pr-04-2014-0083 https:// doi.org/10.1108/PR-04-2014-0083

Lester, M. (2011). A study of the innovation, creativity, and leadership skills associated with the college-level millennial generation. Ann Arbor, Michigan: ProQuest LLC.

Mohelska, H., \& Sokolova, M. (2018). Management approaches for Industry 4.0: The organizational culture perspective. Technological and Economic Development of Economy, 24(6), 2225-2240. doi:10.3846/tede.2018.6397 https://doi.org/10.3846/tede.2018.6397

Müller, J. M., Kiel, D., \& Voigt, K.-I. (2018). What drives the implementation of Industry 4.0? The role of opportunities and challenges in the context of sustainability. Sustainability, 10(1), 247. doi:10.3390/su10010247 https://doi.org/10.3390/su10010247

Nedelko, Z. (2015). Ethics of managers in Slovenian public administration. Management, 20(2), 23-47.

Nedelko, Z., \& Potočan, V. (2019). Personal values as drivers of managerial innovation: Emerging research and opportunities. Hershey: IGI Global. https://doi.org/10.4018/978-1-5225-3250-7

Nedelko, Z., Mulej, M., \& Potočan, V. (2017). How to requisitely holistically consider internal gaps of business ethics. Kybernetes, 46(6), 914-932. https://doi.org/10.1108/K-01-2017-0027

Ng, E. W., Schweitzer, L., \& Lyons, S. T. (2010). New generation, great expectations: A field study of the millennial generation. Journal of Business Psychology, 25, 281-292. https://doi.org/10.1007/s10869-010-9159-4

Perrow, C. (1991). A society of organizations. Theory and Society, 20(6), 725-762. doi:10.1007/BF00678095 https://doi.org/10.1007/ BF00678095

Piccarozzi, M., Aquilani, B., \& Gatti, C. (2018). Industry 4.0 in management studies: A systematic literature review. Sustainability, 10(10), 3821. doi:10.3390/su10103821 https://doi.org/10.3390/su10103821

Piciga, D., Musek, J., Kovačev, J., \& Peklaj, C. (1992). Values of slovene in transitional period (in slovene). Ljubljana: Pedagoški inštitut pri Univerzi v Ljubljani.

Potocan, V., Nedelko, Z., Peleckienė, V., \& Peleckis, K. (2016). Values, environmental concern and economic concern as predictors of enterprise environmental responsiveness. Journal of Business Economics and Management, 17(5), 685-700. Retrieved from https://doi. org/10.3846/16111699.2016.1202315 https://doi.org/10.3846/16111699.2016.1202315

Prifti, L., Knigge, M., Kienegger, H., \& Krcmar, H. (2017). A competency model for “Industrie 4.0" employees. Proceedings der 13. Internationalen Tagung Wirtschaftsinformatik (pp. 46-60). St. Gallen: WI 2017.

Roblek,V.,Meško,M., \& Krapež,A.(2016).Acomplexview of Industry4.0.SAGE Open,6(2),1-11.https://doi.org/10.1177/2158244016653987

Roccas, S., \& Sagiv, L. (2010). Personal values and behavior: Taking the cultural context into account. Social and Personality Psychology Compass, 4(1), 30-41. https://doi.org/10.1111/j.1751-9004.2009.00234.x

Rokeach, M. (1973). The nature of human values. New York: The Free Press.

Rokeach, M. (1979). Understanding human values: individual and societal. New York: The Free Press.

Sagiv, L., Roccas, S., Cieciuch, J., \& Schwartz, S. H. (2017). Personal values in human life. Nature Human Behaviour, 1, 630-639. https://doi. org/10.1038/s41562-017-0185-3

Schneider, P. (2018). Managerial challenges of Industry 4.0: an empirically backed research agenda for a nascent field. Review of Managerial Science, 12(3), 803-848. doi:10.1007/s11846-018-0283-2 https://doi.org/10.1007/s11846-018-0283-2

Scholz, R. W., Bartelsman, E. J., Diefenbach, S., Franke, L., Grunwald, A., Helbing, D., .. Pereira, G. V. (2018). Unintended side effects of the digital transition:european scientists' messages from a proposition-based expert round table. Sustainability, 10(6), 1-48. https://doi. org/10.3390/su10062001

Schwartz, S. (2012). An overview of the Schwartz theory of basic values. Online Readings in Psychology and Culture, 2(1), 1-20. https://doi. org/10.9707/2307-0919.1116

Schwartz, S. H. (1992). Universals in the content and structure of values - theoretical advances and empirical tests in 20 countries. Advances in Experimental Social Psychology, 25, 1-65. https://doi.org/10.1016/S0065-2601(08)60281-6

Schwartz, S. H. (1994). Are there universal aspects in the structure and contents of human-values? Journal of Social Issues, $50(4), 19-45$. https://doi.org/10.1111/j.1540-4560.1994.tb01196.x

Schwartz, S. H., Cieciuch, J., Vecchione, M., Davidov, E., Fischer, R., Beierlein, C., .. Konty, M. (2012). Refining the theory of basic individual values. Journal of Personality and Social Psychology, 103(4), 663-688. https://doi.org/10.1037/a0029393

Sessa, V., Kabacoff, R. I., Deal, J., \& Brown, H. (2007). Generational differences in leader values and leadership behaviors. The Psyhologist-Manager Journal, 10(1), 47-74. https://doi.org/10.1080/10887150709336612

Spath, D., Ganschar, O., Gerlach, S., \& Hämmerle, T. (2013). Produktionsarbeit der Zukunft - Industrie 4.0. Munich: Fraunhofer IAO.

Spranger, E. (1928). Types of men. Halle: Max Neimeyer Verlag. 
Takács-Sánta, A. (2004). The major transitions in the history of human transformation of the biosphere. Human Ecology Review, 11(1), 51-66.

Twenge, J. M. (2010). A Review of the empirical evidence on generational differences in work attitudes. Journal of Business and Psychology, 25, 201-210. https://doi.org/10.1007/s10869-010-9165-6

Twenge, J. M., Freeman, E. C., \& Campbell, W. K. (2012). Generational differences in young adults' life goals, concern for others, and civic orientation, 1966-2009. Journal of Personality and Social Psychology, 102(5), 1045-162. https://doi.org/10.1037/a0027408

Verplanken, B. (2004). Value congruence and job satisfaction among nurses: A human relations perspective. International Journal of Nursing Studies, 41, 599-605. https://doi.org/10.1016/j.ijnurstu.2003.12.011

Wang, S., Wan, J., Zhang, D., Li, D., \& Zhang, C. (2016). Towards smart factory for industry 4.0: a self-organized multi-agent system with big data based feedback and coordination. Computer Networks, 101,158-168. https://doi.org/10.1016/j.comnet.2015.12.017

Weber, J. (2017). Discovering the Millennials' Personal Values Orientation: A Comparison to Two Managerial Populations. Journal of Business Ethics, 143, 517-529. https://doi.org/10.1007/s10551-015-2803-1

\section{Authors}

Rok Črešnar is a PhD candidate at the University of Maribor, Faculty of Economics and Business, Slovenia. His main research interests are in general management, business development, productivity management, knowledge management, social psychology, business ethics, and management challenges in Industry 4.0. He is actively cooperating in international academic conferences and research projects and has practical professional international work experience from Ireland. He is currently a head of the marketing department in Mehanizacija Miler d.o.o.

Senta Jevšenak is a master student of sociology and pedagogy at the University of Maribor, Faculty of Arts. She is currently employed as a youth worker and program manager in the MCC youth center in Celje. Her main research interests are in youth development, youth economic questions, and in methods of working with youth. She is also interested in special needs children and methods of working with them in order to help them develop.

\section{Učinek milenijcev: kako lahko njihove osebne vrednote oblikujejo prihodnje poslovno okolje v Industriji 4.0?}

\section{Izvleček}

Temeljni namen tega prispevka je oceniti, kakšen vpliv bodo imeli milenijci na prihodnje poslovno okolje $v$ Industriji 4.0 glede na njihove osebne vrednote. Milenijci prevzemajo vse bolj pomembne vloge v organizacijah, njihove osebne vrednote pa so precej različne od tistih, ki jih imajo starejše generacije. Ta prispevek kaže na to, da so slovenski milenijci na podlagi Schwartzevega testa vrednot, v katerega je bilo zajetih $N=371$ anketirancev, bolj nagnjeni k osebnim vrednotam, ki so povezane z osebno rastjo in osvoboditvijo pred tesnobo, saj kategorično poudarjajo vrednote samopreseganja in odprtosti za spremembe. Manj nagnjeni pa so k vrednotam, ki so povezane s samozaščito in izogibanjem pred tesnobo, kar pa se kaže $v$ tem, da velike pomembnosti ne namenjajo vrednotam samopoudarjanja in konservacije. Ta spoznanja imajo lahko pomembne implikacije pri tem, kako se bo razvijalo prihodnje poslovno okolje v Industriji 4.0, saj lahko le-to postane bolj odprto, razumevajoče, sodelujoče, sprejemajoče in splošno bolj podpirajoče, kar pa ustvari t. i. učinek milenijcev. Čeprav so milenijci glede na svoje osebne vrednote dobro pripravljeni na prihodnje poslovno okolje, bodo organizacije, če jih bodo hotele zadržati, primorane spremeniti svoje organizacijsko okolje, da bo le-to bolje odsevalo poglede milenijcev.

Ključne besede: milenijci, Industrija 4.0, osebne vrednote, predvidevanje poslovnega okolja, poslovna etika, digitalizacija, Schwartzev test vrednot 